\title{
RESET
}

Recherches en sciences sociales sur Internet

\section{Addiction Diagnoses as Involvement Controls}

The Pragmatic Value of Psychiatric Definitions of the Situation

Le diagnostic d'addiction comme contrôle de l'engagement dans les interactions.

Une perspective pragmatiste sur les définitions psychiatriques des situations.

\section{Michael Dellwing}

\section{(2) OpenEdition}

Journals

\section{Electronic version}

URL: http://journals.openedition.org/reset/122

DOI: $10.4000 /$ reset.122

ISSN: 2264-6221

\section{Publisher}

Association Recherches en sciences sociales sur Internet

\section{Electronic reference}

Michael Dellwing, « Addiction Diagnoses as Involvement Controls », RESET [Online], 2 | 2013, Online since 01 July 2013, connection on 10 October 2020. URL : http://journals.openedition.org/reset/122 DOI : https://doi.org/10.4000/reset.122

This text was automatically generated on 10 October 2020 .

(c) Association Recherches en sciences sociales sur Internet 


\title{
Addiction Diagnoses as Involvement Controls
}

\author{
The Pragmatic Value of Psychiatric Definitions of the Situation \\ Le diagnostic d'addiction comme contrôle de l'engagement dans les interactions. \\ Une perspective pragmatiste sur les définitions psychiatriques des situations.
}

\section{Michael Dellwing}

\section{Introduction}

1 "Internet addiction" has steadily made its way into a mainstream that is more willing than ever to medicalize social conflicts (Conrad \& Schneider, 1985) and to cede responsibility for them to psychiatry.

2 Sociology has long been critical towards the bio-somatic medicalization offered by psychiatry and the concomitant tendency to reduce complex social-interactional dynamics to simple answers of "health" and "illness," of "ordered" and "disordered" behavior and personalities ${ }^{1}$, instead of identifying psychiatry as a form of social control (Szasz, 1974: 260; Scheff et al., 1984: 19; Castel, 1983; Ussher, 1992, 1997; Showalter, 1987; Ehrenreich \& English, 1973). Many sociological treatments of this subject matter have therefore treated "addiction" as a socially constructed meaning, an objectification of a complex social situation in "disease" terms and a subjectification of it through its location "in the person." This has often taken the form of harsh criticism of psychiatry as a naïve simplification of difficult and "thickly peopled" problems (most famously in antipsychiatry, cf. Szasz, 1974; Cooper, 2001 [1967]; Laing, 1978; Basaglia, 1987, etc.).

Following this critical stance, I will not treat "addiction" as an illness, but rather treat the treatment of it as an illness in everyday life as a tool that pragmatically resolves a doubtful situation. Following Erving Goffman, the addiction trope helps people in social conflicts over "involvement" (1963), i.e. over the attention and focus people bestow on social situations and relationships. When one person is involved deeply in affairs that the other person thinks take them away from their "correct" involvements, "addiction" 
can come up as a tool to stigmatize the unwanted involvement and enforce a return to wanted involvements. It is important to emphasize in this context that "correct" is a partisan judgment, not a given attribute of involvement: rather than assuming that there are "natural" and "unnatural," "healthy" and "diseased" forms of involvement, these must be seen as group expectations. Equally, I will not treat these expectations as "norms," the breach of which leads to addiction ascriptions: they are, at first, nothing but local pressures that the affected can heed, deny, play with and modify. "Addiction" is a move in this game in which involvement is negotiated - a tool to negotiate the reality of "adequate involvement." The medicalization of this tool allows claimants to enlist the power of the medical establishment and the credibility of its putative "scientificity" to support their claims. Only if successful can it be used to enforce an involvement other than that which the "offender" presents to their surroundings.

\section{"Internet Addiction"}

4 As is well known, the diagnostic category of "Internet addiction" was born from a joke. On a mailing list in 1994, Ivan Goldberg utilized the common terminology associated with addictions to ironically describe the experience of immersing oneself in the thennascent Internet, which then only consisted of slow exchanges of text in e-mails and message boards (Walter \& Schetsche, 2003: 10). He then coined the term "Internet Addiction Disorder" to describe people's "retreat" from the "real" world in favor of interaction on these boards and in email exchanges, again, in jest.

5 From this joke on, the concept has made its journey to official semi-recognition. The advent of the development of this disorder "in earnest" is attributed to Kimberly Young (Walter \& Schetsche, 2003: 11; cf. Young 1997), who initiated questionnaire research to validate such a "retreat"-disorder in an effort to localize classical addiction tropes in those who spent "too much time" online. Though "Internet addiction" is not presently an officially recognized "disorder" in the sense of having gained entry into the bibles of disorders, the DSM-IV (APA, 2000) or ICD-10 diagnostic catalogs (Clark, 2011: 55), it can be considered "recognized" in practice, as it is used to treat patients. A survey among Swiss psychiatrists found that more than $80 \%$ of psychiatrists currently consider it a psychiatric problem, and of those who receive an Internet addiction label, 32\% receive psychotherapeutic treatment and $34 \%$ receive combined psychotherapeutic and pharmacological treatment (Thorens et al., 2009: 119). At the rate of the DSM's expansion (cf. Kirk \& Kutchins, 1992, 1997; Caplan, 1995) ${ }^{2}$, it will undoubtedly soon be knighted to the rank of official disorder as well. Murali and George tellingly speak of a disorder "not yet recognized"' (2007: 24) before proceeding, in the language of self-evident fact, to put the number of "affected" persons inbetween two and five million (24).

6 The first rule of organizational sociology is, of course, that institutions seek to protect and enlarge their realm of influence and responsibility. It is thus not surprising that psychiatrists will gratefully accept the competence for handling more interactional conflicts. As a scientific endeavor, the way to such expansion is to provide scientific studies supporting this expansion by showing how treatment helps ease the troubles of the affected and how brain chemistry can be linked to this particular set of troubles and to easing them. In recent years, scholarship critical of studies that allegedly "prove" the biomedical basis of these troubles and the effectiveness of medical treatment has become more and more forceful (Moncrieff, 2009; Kirsch, 2009; Whitaker, 
2010, 2011), but that is not a debate I will engage in here. I consider this critical perspective fully convincing, but the objective of this piece is more practical than debating the reality of biomedical claims concerning psychiatric "diagnoses." I will rather develop a sociological framework for reconceiving psychiatry as a pragmatic enterprise; an institution that produces "disorder" as a pragmatic definition of the situation in order to solve doubtful situations. This involves, as a necessary prerequisite, a suspension of belief in behavioral problems as "illnesses". But at the same time it allows us to identify the pragmatic benefits of this belief in everyday life: actors use "Internet addiction" as an illness ascription. With this, they deploy a social meaning to persons-in-conflict and thus take sides in that conflict. Insofar as addiction is ascribed to one person, "legitimate gripe" is ascribed to the person whose normality is offended by the putative addict's behavior. Thus, this deployment entails the support of one definition of the situation over another.

\section{Pragmatism}

7 This paper will use a pragmatist-interactionist approach (Prus, 1996, 1997; Fine, 2010) to analyze the social achievement of meaning and the social aims and consequences that these achieved meanings themselves achieve. Like other interpretive sociologists, pragmatists oppose realist epistemologies and abandon the question of "real" meanings to instead see them as humanly produced. To pragmatists, meanings are local and situational handles on a plural and fluid world that creates doubts that actors have to deal with. Dewey proposes that "the natural approach to [...] sentences [...] is not 'Do they get it right?', but more like "What would it be like to believe that?" (Rorty, 1982: 163). Pragmatists conceive descriptions as a part of human tool-making capacity (Rorty, 1982, 1989; Fish, 1989; Dellwing, 2011a). They are definitions "of the situation in a situation" (Dellwing, 2011b: 205) that come up in contexts and with aims. Definitions of the situation are thus ways of "puzzle-solving" (Rorty, 1982: 193); fixing a doubtful situation to make concerted action possible. Meanings, in this view, are "simply tools of coordinating our behaviour with those of others", and claiming a definition "is to argue about what we should do" (Rorty, 1999: xxiv) in a concrete context. Definitions of the situation achieve, as a central attribute, the adjustment of action toward objects, together with others.

8 When we see definitions of situations as a central part of joint action, conflicts come up as a disturbance of shared definitions and joint actions. Acting together presupposes acting towards an object with the same definition of the situation. But following pragmatism's outward emphasis, the internal definitions of the situations the actors may carry are not important; they are in any case invisible. Conflicts, from a pragmatic perspective, come up when joint action is stalled and a resolution must be found that reintegrates action by reintegrating definitions of the situation: it is only in situations of conflict that the shared definitions of the situation, usually hidden, come to the fore.

In sociological scholarship, this practice of reintegrating definitions to overcome a breach in joint action has often been researched under the heading "aligning actions" (Stokes \& Hewitt, 1976). These are "various tactics, ploys, methods, procedures and techniques" (Lyman \& Scott, 1986: 838) that include, but are not limited to, disclaimers (Hewitt \& Stokes, 1975), motive talk (Mills, 1940; Blum \& McHugh, 1971; Albas \& Albas, 2003), quasi theorizing (Hewitt \& Hall, 1973), excuses and explanations (Lyman \& Scott, 
1986; Goffman, 1971). They supply ready tools for "aligning individual lines of conduct when obstacles arise in its path" (Stokes \& Hewitt, 1976: 839), to reestablish common, joint action (Blumer, 1986 [1969]). With their help, "interaction may proceed toward a social object" (Stokes \& Hewitt, 1976: 842) when that joint action hits obstacles, when "some feature of a situation is problematic" (Stokes \& Hewitt, 1976: 838). "Problematic" is not a naturally arising state of an interaction, however, but an active achievement that comes up when an interaction partner dramatizes irritation regarding an action of another, who is then called upon to make amends and realign (though resistance is, of course, a possibility; cf. Dellwing, 2013). Psychiatry provides a strong form of alignment, and the addiction description of persons works as one particular instance of such psychiatric alignment. In this framework, the right questions therefore are: When and where do psychiatric tools come up; what do they do; in what context; for whom? Empirically, then, there is such a disease because it is recognized, diagnosed, and acted upon by medical professionals and lay people. It is a situation of the definition that is used, and one that has clearly recognizable consequences.

\section{Psychiatry Pragmatism: Diagnoses as Tools}

Psychiatry as an institution defines cases as problems and then "solves" them. From the psychiatrist's perspective, patients and problems are no longer problematic, but become objects of cure after a diagnosis has been used on them. Psychiatry thus provides tools for the alignment of action when divergences disrupted it. As such, it is one tool among many; the entire field of aligning actions discusses tools of this sort, and psychiatry is not qualitatively special in this regard. However, it is special in magnitude and in the institutional support for definitions of the situation it provides.

11 Analyzing psychiatric intervention as a specific form of aligning action allows us to reconceptualize the situations in which these alignments arise as scenes of definitional rifts and unaligned action (rather than as "symptomatic behavior" and "disease"). It conversely allows us to reconceptualize the practice of psychiatry as, as Erving Goffman famously termed it, a "tinkering trade" (1961: 321) that deals with these disalignments. Psychiatric categories, Bowers argues, constitute "only the provision of a name, not of a name and explanation [...] There are only names of syndromes and statistical prognoses, plus some pragmatic treatments" (Bowers, 1998: 74).

The classic formulation of a pragmatist approach to "mental illness" is offered by Erving Goffman. Lofland writes "Goffman is an Emerson, a James, a Dewey, or a Mead" (Lofland, 1984: 12). Goffman stated bluntly that he was not animated by deep respect for the discipline (1961), but still conceded that if psychiatry didn't exist, it would have to be invented (1972). It provides a service that no other alignment-producing institution can easily absorb: it mobilizes medical-scientific support in favor of one party in a social conflict over definitions of the situation. A sociological perspective, especially with interpretive inclinations, refuses to decide on "reality", "rationality", or "appropriateness" of these definitions. It is merely interested in the empirical processes in which these definitions are supported, how coalitions for their support are built, and what social consequences these processes entail.

13 This is the core of Goffman's pragmatist approach to psychiatry: he is interested in situations in which ascription of mental illness comes up as moves in a social conflict about definitions of the situation, i.e. about meanings that people ascribe to themselves 
and others, to their relative roles and positions, and to objects in their vicinity: "Mental symptoms (...) are acts by an individual which openly proclaims to others that he must have assumptions about himself which the relevant bit of social organization can neither allow him nor do much about" (Goffman, 1972: 356). They are acts by which the other person "secedes" in his or her definition of reality. As definitions of the situations live between people rather than in them or in objects, when one person in significant relationships reneges on these shared definitions, others "cease to be sure about themselves" (Goffman, 1972: 366) and their definitions as a consequence as well. This definitional disloyalty of a deep member threatens the group's safety coalition about their world. Insofar as the relationships are supported through joint action, the demise of joint definitions signals the demise of these relationships: others depend not just on the definitional loyalty of their friends and colleagues, but also on their loyalty when it comes to maintaining negotiated role-positions. Reneging on shared definitions of reality can thus quickly be seen as to entail reneging on the social relationships and the normalities that they have held so far in them themselves. The title of Goffman's essay, The Insanity of Place, points to this angle: those defined as "mentally ill" are those who "break rank," who do not keep their place in the wider sense of not keeping with role performance expectations, i.e. with the actions others expect based on their definition of the situation. In that sense, a broken expectation is already indicative of a conflict of definitions of the situation. However, whether this broken expectation becomes an actual conflict depends on the actors acting on their irritation, i.e. it depends on them halting joint action until aligning actions realign it. Others try to reinforce the old role or negotiate a new one, and the role-shifting person refuses to play along. ${ }^{4}$

Psychiatry does not take charge of these situations right away: it is not the first line of role defense. Acts can be sanctioned, the deviant pressed back into his role with anything from persuasion to force. Only when these attempts remain unsuccessful and the role-breach is sustained over these reactions does psychiatric control arise. In this sense, what comes to be known as symptoms "deviate from other deviations. A person who suddenly becomes selfish, heartless, disloyal, unfaithful or addicted can be dealt with. If he properly shows cause or contrition, he can be forgiven; if he is unrepentant but removable he can be redefined. In either case, his others can come to terms with him" (Goffman, 1972: 366) When he is unrepentant, i.e. other means of social control fail, and also cannot be removed, i.e. cutting ties to the partner-in-definition is seen to not be an option, a cul-de-sac arises. The person sustains his role-breach and yet he is kept in the social circle. He makes trouble from the inside.

Psychiatric re-definitions of the person and his behavior help remedy this hopeless situation by providing a definition of the situation that retains the "ideal" person within the circle, but defining the real person to be "buried" and trapped behind a false façade maintained not by the person but by the "disease". The irritated persons consider that the actions that alienated them were not actions of the "real person" but rather involuntary symptoms. At the same time, the flesh-and-blood person can be removed and institutionalized under the definition of medical treatment in his own best interest, even if he violently protests it. The ideal person remains inside the social circle, the offending diseased person is removed, and since removal happens under the definition of treatment it happens under the definition of care for the needy. Psychiatry thus provides a definition of the situation that allows a "loving removal"; a physical removal that is caring and helpful and thus not an ideal removal at all. 
This is where, following Goffman, psychiatry would have to be invented did it not exist. The solution it offers is extremely practical to maneuver one's way out of a cul-de-sac, by defining the social relationship that may "appear" broken as "in fact" continuing, only buried by "merely physical" blocks that keep the "real" person from "coming through". This realignment practice is complete when the person who "caused" the irritation engages in "the greatest ritual work of all": ascribing illness as the cause for his or her definitional infidelity. "Therapy", in addiction ascriptions, is successful when the offending actor defines his or her action as a role-breach as well. In the vernacular of therapy, this is "recognizing one has a problem"; the famous "first step" towards a cure. This achieves the final step, realigning the physical person with the ideal one that had been feigned to keep up relations all along. By retroactively taking the disease role that the others had ascribed to him/her, the "patient" ratifies the feigned role after the fact and allows it to be the official and accepted ascription on his role breach. Taking the role again, he retroactively states that he, correctly understood, had always held it. This realignment practice is widely usable, as the ongoing expansion of the field of psychiatry tends to attest. It is the practical use, and the social acceptance of that use, that make its consequences real.

\section{"Addiction" as a Tool for Enforcing Involvement}

17 Analyzing the different, overlapping and fuzzily delineated (Kirk \& Kutchins, 1992: 239) "disease categories" offered by psychiatry not as "truths" about the world but rather as pragmatic tools, ways to get out of different cul-de-sacs, solutions to different kinds of conflicts over social definitions of reality, would be a project in its own right. The present paper is only concerned with one of them: internet addiction ascriptions. The interactional disturbance that is aligned through this categorization can already be found in Goffman's analysis: addiction ascriptions control the balance of involvements in social life and provide accounts for a specific kind of "breaches of involvement" that Goffman calls "away” (1963: 69 ff.).

Goffman notes that, in any social situation, there are different dominant and sideinvolvements to be balanced (Goffman, 1963). Involvements are calls on a person's attention and on their dramatization of being present, interested and up to speed with what is going on in the situation and the others' expectations of it. To be "away" is to disengage from any acceptable dominant involvement to fall into reveries, engagements with minor and socially unimportant matters, fugue states, etc. (Goffman, 1963: 43). There are acceptable phases of "away," i.e. waiting for the main engagement to start (in waiting rooms), being transported to main engagements (on a train), being in accepted "disengagement zones" (like a beach or a sauna), disengaging to involve oneself with "nonpersons" or "incomplete persons" (like children or pets), or be in a disengaged reverie for very short periods of time, ready to "snap back" (p. 74) to the dominant engagement at any point. These kinds of "away" do not infringe on the involvements others expect to be maintained, and leave the actors ready to underscore the importance of the important engagements when called upon to do so, either by breaking the "away" phase immediately or by having accounts for being away that underscore one's respect for the dominant involvement.

One of the mainstays of psychiatrically relevant behavior, Goffman contends, consists of unexcused and unexplained presentations of being "away" (Goffman, 1963: 69 ff.), i.e. 
those that the surroundings define as unacceptable and those the explanations for which other actors do not accept. Psychiatrically relevant disinvolvements are those that cannot be broken by outside interruption or that cannot be accounted for in ways that respect the main involvement. These kinds of "awayness" appear to onlookers as what Goffman calls "occult": "a kind of awayness where the individual gives others the impression, whether warranted or no, that he is not aware he is 'away"' (p. 75). That is, when the individual is not aware that the outside even defines one's actions as "away" in the first place. These can be schizophrenic aways where unshared fears are followed or voices no one else hears are heard: emotional aways where emotional dramatizations are presented that others do not consider proper. All of these are, then, involvements defined as dominant by those who engage in them, while the outside defines them as "away". The "addiction away" is a question of time and involvement management of a more direct kind. Resources, attention and simple time are given to tasks that the surroundings do not classify as a legitimate activity - a legitimate involvement that is.

These activities are then the objects of a major conflict regarding the definition of the situation: these "away-involvements" include activities that are "patently tasklike but not 'understandable' or 'meaningful"' (Goffman, 1963: 75). Addiction covers the involvements that are understandable to the outside, but not acceptable. They do not "lack meaning" in their own right (they are meaningful to the persons who engage in them and can be understood by others), but they lack a common definition of appropriateness in the light of other expectations. The actor does not define his or her action as an "away" at all, but rather as a legitimate and meaningful involvement in its own right, and refuses "away" as a common definition by refusing to break it for other involvements that observers consider dutifully dominant. However, the action based on these meanings appears meaning- and pointless from an outside perspective: "the others present cannot 'get at' the general intention by which the individual is apparently governed, and cannot credit the offender's account should he offer one" ( $p$. 74).

21 Addiction ascriptions fall squarely into this category. Seeing cases in which addiction ascriptions are used when there is a failure to define "away" together allows us to understand the social dynamics of "addiction" definitions. "Addiction" is a tool to socially control unaccepted "aways" and to enforce the joint honoring of (what one side considers to be) dominant involvements. These involvements are "dominant" only to some at the outset of the situation, and the "away" is, in fact, treated as a dominant involvement by the "offender". The addiction trope is a way to produce and enforce alignment concerning the definition of dominant involvements.

These instances of conflicts over the "correct" definition of a main involvement and a breach of it as "away" can be plentiful. Gambling, states of altered consciousness through substances, involvement in the pursuit of sexual encounters, etc., can all appear, to outsiders with their own expectations of dominant involvement, as illegitimate and disturbing "aways". Addiction is a behavior that others so label to (re-)enforce dominant involvements and thus re-enforce existing role distributions and social "places". Therefore, "addiction" is regularly an outside ascription. The "afflicted" generally have to be brought to understand themselves as "addicted" by advocates, experts or moral entrepreneurs (Schetsche, 2007: 122), but this is a relational and contextual achievement. If addiction is a tool in interpersonal conflicts 
over involvement, there is no addiction ascription without an interpersonal dynamic. This is, of course, the gist of the interactionist sociology of deviance and Howard Becker's famous definition that "deviant behavior is behavior that others so label" (Becker, 1963: 9), and so label for specific purposes in specific contexts.

From a perspective that focuses on the processes in which joint definitions of involvement are produced, this "recognition" is merely, and non-normatively, an alignment. Disaligned definitions of involvement are realigned when the "offender" redefines their own activity as an "away", breaks from it, and re-engages what the other side defined as "dominant". It is, thus, an alignment in favor of the person(s) whose definition of "dominant engagements" was irritated and an alignment of action toward the expectations of those persons. What appears to the involved entrepreneurs as "creating awareness", a conceptualization based on the definition that the addiction ascription captures an objective truth, appears to constructionist and pragmatist sociologists alike as a struggle to fix a contingent definition of a situation that could also have been fixed differently.

This is iconoclastic and no radical position at the same time. On the one hand, it is necessary for the medicalized talk of symptomatology to objectify symptoms in descriptive catalogs and subjectify them by locating them exclusively within the person. For this purpose, psychiatric institutions need stripped-down "descriptive" elements that can be listed and checked off in a decontextualized manner. On the other hand, psychiatry has always been explicit about handling social conflicts and includes this recognition within the formal catalog that seeks to expunge this situated nature of category application. Most DSM diagnoses entail, as a necessary condition, the "symptom" of a disruption in social relationships and function. The presence of "a disruption in social relationships" as a separate but necessary category that stands alone de facto makes the social disruption the core "symptom", hidden in plain sight behind a list of more objective-sounding "descriptive" conditions.

\section{"Internet Addiction" and the Enforcement of Close Involvements}

Addiction ascriptions, then, come up in battles over involvement. "Internet addiction" comes up in battles over what I could call "cyberinvolvement". As such, they come up within conflictual, "thickly peopled" (Strauss, 1993: 25) and deeply contextual social situations.

A summary piece on the "effects" of Internet addiction reads like a list of social expectations by the most socially accepted reference groups: the family, partners and superiors at work and in college. Studies on the "problems" caused by "excessive" use of the Internet cite that "respondents reported that Internet use had interfered with either their academic work, professional performance, or social lives" (Chou et al. 2005: 364). Kimberly Young (1997: 237) also names "academic failure, reduced work performance, and even marital discord and separation" as consequences of "internet addiction." Murali and George (2007: 25) note that supposed "internet addictions" cause "people to neglect sex, grooming, work." The problem "caused" by excessive use of the internet is seen as a "failure to manage time" (Chou et al. 2005: 364); these fields are easily identifiable as conflicts over involvement in which involvement in the 
internet or in online games clashes with those of these reference groups: family, employers, teachers. This is the general triangle of time control in internet addiction cases: The family enforces its time against what is perceived as "alone-time" or "withdrawn time," against what looks like an "away" from their perspective; the employer and the school defends their time and the presence concerning their tasks, seeing internet time as an "away" from homework and preparation and from alertness and presence concerning employment expectations. The family is by far the biggest involvement enforcer in this picture.

\section{Family and Close Social Relationships}

Close relationships do not necessarily come with set time commitments. Many relationships endure long-distance setups with infrequent meetings, commuting to work that draws attention away from the family for most of the day, in some arrangements even for entire weeks. There is no solid set of expectations on how much time has to be spent with the family. Participants negotiate the value and hierarchical position of their social relationship vis-à-vis other social relationships to determine super- and subordination, i.e. which relationship takes precedence in an involvement conflict. Whatever arrangement there is in a particular family is negotiated within it and with an eye to the looking glass self-expectations attributed to outside spectators who will judge the family and negotiate the family members' own judgments with them. This joint, thickly peopled and deeply social determination of family time schemes is a complex game of thrones. In it, participants are often expected to at least privilege the family as a matter of lip service; in practice, work involvements tend to take precedence in action, and work involvements can easily be used to reduce family involvement: It is a banal point that if someone works as a broker and spends night and day in front of a networked computer connected to the world's stock market to an extent that wife, children, and friends are "neglected," ascribing an "internet addiction" would be at best odd.

It is in this context that participants enforce family involvement against those who are seen to place an undue hierarchical position on non-family, non-employment involvement. Indeed, this is the main area in which "internet addiction" is used as an account for illegitimate awayness and as a tool to control this awayness. "The greatest negative impact tends to be on family and social life, as excessive time spent online often results in neglect of family, social activities and interests" (Murali and George 2007: 25). Shapira et al. (2000: 269) report what they call "significant social impairment (e.g. family strife or divorce) in 19 (95\%) subjects". This is already a partisan valuejudgment in which the expectation of one side of a relationship, and those most likely to be supported by social coalitions around the family, is given normative status and defended by way of calling the failure to honor these particular expectations an "impairment". The fact that it "disrupted marriages" (see also Young, 1997: 240) and caused "relationship problems", disrupted expected interactions in the sexual and romantic departments as well as in the context of taking care of children and making time for friends (Chou et al., 2005: 364) is seen, in the clinical view, as an objective irritation rather than the irritation of particular others in particular relationships. The literature goes as far as using the dramatic term “"cyberwidow' [...] to refer to the neglected partners of Internet addicts" (Murali \& George, 2007) for those whose use of the Internet the literature feels secure to call "excessive" (Young, 1997: 240). 
What transpires in these situations is that "dependents often preferred their on-line friends over their real-life relationships" and "gradually spent less time with friends and family in exchange for solitary time in front of a computer" (Young, 1997: 240). They "neglected their spouses in place of continual electronic rendezvous with on-line lovers, leaving no quality time for their marriages". This irritated other concrete persons, who "first rationalized the obsessed Internet user's behavior as 'a phase,' in hopes that the attraction would soon dissipate". When that did not happen, "arguments [...] soon ensued", and the literature stays true to its partisan line in calling the resistance the Internet users put up against this communication of irritation as "denial exhibited by Dependents". When they "became angry and resentful at others who questioned or tried to take away their time from using the Internet", this can only appear to clinicians as another symptom of addiction: an "addict's response", not the reaction of a person defending her autonomy against those who presume to know better than she does how she should spend her time. To enlist psychiatry to break these "illegitimate" involvements necessitates this partisan interpretation: no action is possible without determining the locus of the issue, and to "find" it within the person and his or her "unnatural" choices of involvement is what allows a medicalized reaction in the first place. Psychiatry here appears clearly as an involvement control tool that naturalizes one set of expectations, generally that of the spouse, over another set, that of the person spending time online (and perhaps of those with whom that time is spent).

\section{Employers and Schools}

Other than family members, employers, teachers and school administrators define nonschool and non-employment involvements as "aways". The literature bemoans that "Internet addiction can lead to poor academic performance in school and college" (Murali \& George, 2007). In other words, that deep commitment to one's studies suffers when time is spent on "the Internet". Again, the clear partisan nature of diagnosis is evident here. Young is quick to term Internet use that is not directly related to college assignments as surfing "irrelevant web sites," and is equally certain that online games come "at the cost of productive activity" (1997: 270), thereby explicitly assuming that "productivity" is a clear and determinable fact rather than a perspective-dependent and therefore conflictual definition of the situation. "Such Internet misuse", as Young (1997: 270) calls these activities, leads to a lack of sleep and therefore reduced academic performance. They thus lead to an irritation of the very partisan expectations of teachers and possibly parents. One of the perhaps funniest "diagnostic descriptions" in this regard can be found in Chou et al. (2005): "Teachers may notice that fewer and fewer students are willing to take early morning classes, and some of those who do register for morning classes regularly come in late. It has also come to the attention of some school administrators that some students get poor grades or are placed on academic probation because they spend too much time on the Internet rather than on their studies" (p. 364). There is a distinct air of surreality in this gripe that exposes the ways in which these ascriptions come up simply to enforce one set of involvement expectations over another one that is quite understood, but seen as inappropriate. 


\section{The Self}

31 As obvious as reformulating these diagnoses as involvement control mechanisms may be, they have not yet arrived at the heart of the medical model's utility. Using medical descriptions and medical intervention to enforce a party's definition of an involvement as an illegitimate one, and thus as "away", entails a redefinition of roles which includes the acceptance of that role by the controlled. Many of the involvement breaches are thus socially defined as breaches of "correct" involvement with the self. Studies cite what they consider "norm breaches", as for example neglect of "food and health", as a "symptom" of Internet addiction (Murali \& George, 2007).

Thus, the official account charges the neglect of self-involvements: grooming, food, sex and social life. One interesting aspect is the naturalization of sex, which is at first the naturalization of the partner's expectation that their loved one make time for sexual involvement with them, then shifted to the putative "addict" as an offense against their own "natural" sex drive. When these "descriptive categories" are institutionalized, partnerless "victims" can even have their partnerless status ascribed as a symptom, meaning that their surroundings will claim that they should have "others" that should be more important than their other involvement, and that not seeking this "legitimate" involvement is in itself a problem. This points towards another naturalization: the outside expectations, once naturalized, become ascribed as the personal "real" interests and drives of the afflicted who is bulldozed by the "addiction." Among the things neglected named by the summary text, we can find frequent ascriptions of outside interests as the afflicted's own interests.

This is, of course, the classical twist in the addiction trope. Though it prominently supports the expectations of others, it locates the interest and will to follow these expectations within the afflicted themselves. The addiction makes people do things they normally would not do and present the face of the disease rather than their true self. This is an ingenious account, as Goffman already noted, to protect broken sociality. The surrounding persons who have their expectations broken can attribute the breach to the disease rather than the person: the hurtful things done by that person are then not to be understood as an expression of the "real" intent to ignore and neglect them. The "real" person would never do this, and once this real person is reestablished, the expectations will be kept once more. In keeping these expectations, they keep in place the relationships that underwrite them, and thus return to social places they never "really" left, as if what left that place was a "what" - the disease - and not a "who" in the form of the person. The status quo ante is reestablished when the afflicted engages in ritual accounting work to divorce his present self from the "it" that overwhelmed it, "confessing" in the process that there was this "it". The ritual work that reestablishes the social relationships replete with the expectations that had hold before goes along with a role-taking as "having been ill all along" when the game is successful.

Acceptance takes the form of slow disengagement with the role that others ascribe to those who will become "patients". This takes the form of "marked personal distress over their behaviors" (Shapira et al. 2000: 269). Howard Becker already noted that those who ascribe deviance to others can themselves be seen as deviant by their "victims" (Becker, 1963), and those who are defined as deviant but do not accept this definition will then attempt to avoid or react against those who ascribe these deviant roles: "similar to alcoholics who will try to hide their addiction, Dependents engaged in the 
same efforts to lie or hide how long they spent on-line" (Young, 1997: 240). This lying is a simple strategy to escape sanctions for behavior that the sanctioned do not wish to give up.

\section{Whose Norms?}

35 These "aways" from involvements expected by others, and projected on a supposed "real self" who would control them were s/he sane, could, in a first attempt at turning a sociological corner, be considered irritations of social norms instead of natural symptoms: cleanliness, attention to family, a work ethic, the maintenance of relationships, etc. However, that would not only be superficial and obvious, it would also serve to steamroll the complexity of a plural social world. Norms, though a staple of sociological argumentation, are but a shorthand, and to explain any social action through recourse to "norms" is to not explain the dynamics of the situation at all. In any actual situation, norms are legitimating reasons cited for the support of action. Norms, however, do not act. Only people act, and concrete people have to interpret, i.e. define the situation in which they have to interpret the norm with reference to the situation (cf. Dellwing, 2009, 2011a). Every normative judgment is a local, fresh and unavoidably situational and contextual judgment (Fish, 1989). This is not to deny order. It only denies that order is a transcendent force imposing itself without becoming bogged down the muddied waters of the situation. As Gary Fine quotes Charles Edgley, this pragmatist-interactionist stance "makes order fully situational" (Fine, 2010: 355). A pragmatist analysis cannot stop at norms but needs to recognize that social orders are locally negotiated and subject to the contingent and chaotic internal dynamic of emergent situations (cf. Shalin, 1986).

Thus, to merely see these diagnostic criteria as an expression of abstract "social norms" is not only reductionist, it also universalizes someone's interpretation and partisan judgment as "normative" without regard for the situational dynamics and the conflictual sides in them. To merely argue diagnoses as defenses of "social norms," as much sociology of psychiatry tends to do, thus hinders understanding more than it helps. In dubious situations, actors reflexively and purposefully interpret norms in light of concrete issues, doubts and loyalties. Their interpretation of said norms is thus contextual and partisan, so that these situations are not instances of "normative ordering" but of local productions of contextual orders. This requires that we mind social relationships and loyalties, role distributions, authority ascriptions, shared pasts and aims, ongoing conflicts and most importantly the continuous negotiation of all of these as social meanings in "continuous permutations of action" (Strauss, 1993). The right question, then, is not "what social norm are these 'patients' breaking?" but rather: who has what expectations; in what context; with what shared history, concerning involvements? Who enforces them; with which aims; in what relationships and loyalties; with what authority? (cf. Dellwing, 2009).

\section{The Non-Aways}

Another group, one that Brenner (1997) in his survey called "Internet friends", stands on the other side of this conflict: the "affected" showed "trouble with employers or social isolation except for Internet friends" (cited in Chou, Codron, and Belland 2005: 364). In other words, the expectations of one group were broken in favor of the 
expectations of another group and the evaluating outside institution valued one kind over the other.

Dependents enjoyed those aspects of the Internet, which allowed them to meet, socialize and exchange ideas with new people through these highly interactive mediums (Young, 1997: 240)

of course, distinguishing "Internet friends" from "real friends" is a practice long engaged in by scientists who do not regularly use the Internet. In the age of Facebook and the digital world, it is difficult to distinguish the two, and many a relationship thrives only because there are ways to engage in ritual work in social networks where previously there had been no ways to do so in any context. It is for this reason that the authors do not subscribe to the deficit narratives they find in the studies they survey. They note that young people, i.e. those who grew up with a thoroughly normalized view of online communication, reported "strong positive influences on their peer relations" (Young, 1997: 369), as the Internet provides "users with the opportunity to meet new people, provide additional, if not primary, tools for communicating with friends, and create more topics to share with them" (p. 370).

\section{A Game of Involvements}

38 However, the article also defines "time-disruption, leading to interference with academic work, professional performance, daily routines, and so on" as a "negative impact" (Young, 370). The normalizers seem to be unable to help themselves when it comes to reiterating mainstream news accounts of "the Internet". While the descriptions offered in the diagnostic and epidemiological literature allow a glimpse into the interactions and the local conflicts in which these diagnoses appear, their generalized formulation and complete lack of attention to the shared pasts, role distributions and contextual aims in these conflicts make them utterly unable to convey the intricate net that is social interaction as well as the local and intentional use of abstractions in social interaction. When we reconceptualize "addiction ascriptions" as means to control prolonged cases of "away" that someone does not accept because they disturb someone's idea of a correct role position, we can open a whole new field of inquiry. The interesting questions now become whose expectations are enforced in which contexts and constellations. Ethnographic research then has to concern itself with concrete situations in concrete contexts.

This reformulation has, of course, a much wider applicability than merely to Internet addiction ascriptions. Sociological research has long noted how "addiction" is a social role that depends as much on social expectations of "addict roles" and their linkage to specific substances (or, now, activities) as on the chemical compounds found in them (Adler, Adler \& O'Brien, 2012). Using Goffman's ideas on involvement, addiction can be widely seen as a tool to stigmatize forms of involvement that social circles find problematic. Other non-substance involvements that break social expectations can be understood this way. Sex addiction, for instance, is a form of promiscuity and frequent sexual activity that is not only offensive to social circles and/or takes time away from other more legitimate enterprises, but that also, and most importantly, leads persons to use contexts in which they would be expected to have other aims for sex: the person overwrites aims and purposes associated with business or academic interactions and uses these contexts to seek sex rather than the desired results within the field of business or academia. Once we walk this path, we can locate involvement conflicts in 
many disorder categories far beyond the "new addictions". "Classical" addiction stories such as alcoholism also control involvement. Even the most central of psychiatric illness categories can be analyzed as a form of involvement control. Depression, for instance, is a medicalized control narrative for people who spend, in the judgment of their social circle, too much time with negative and problematic thoughts and outlooks, too much time with themselves and in retreat, and upkeep a negative emotionality (even when it is not shown) with too much effort, so that intervention is deemed necessary to "repair" normal involvement with worries, the social circle and negative emotions. Rather than naturalize these ideas of involvement - that there is a "naturally right" amount of self-worry, of emotional display, of activities that others may deem "obsessive", etc., these social controls of involvement involve a normalization of involvement regimes in certain contexts. The task of sociology is to recover these ideas of normality from these efforts of control. It was, of course, one of the achievements of psychoanalysis to investigate these interpersonal dynamics. However, with its own unquestioned abstractions and reliance on tropes like "the subconscious" and its obsession with sexuality, it did not serve to understand the complexities of social interaction as much as it could have. There once was an arm of psychiatry that did concern itself with these: transactional psychoanalysis (Sullivan, 1964; Berne, 1964). This school is incidentally the arm of psychoanalysis that is the most closely related to the Chicago roots of interactionist and pragmatist scholarship. Although their approach still was not sociology (and, most importantly, held on to the idea that pathology was to be corrected), it was much closer than any of the artificially simplified and unrealistically streamlined explanations that have taken over modern somatic psychiatry (cf. Moncrieff, 2009; Whitaker, 2009, 2010; Dellwing, 2010).

To apply the Chicago-sociological interests of pragmatist analysis to psychiatry then means to regain a healthy skepticism when it comes to the biomedical illness-centered psychiatric categorizations that have gained such a strong foothold in everyday life discussions about matters such as the one discussed here. While it is necessary, for scholarly purposes, to abandon this belief in the truth of psychiatric diagnoses in order to be able to analyze the interactional dynamics it overwrites, it is necessary to note that the belief in their truth in everyday life is exactly what gives it its interactional power. It is, thus, a matter of perspectivity: nothing is good or useful in the abstract. Psychiatry is good for certain purposes, from certain perspectives, in certain contexts, for certain groups. Whatever use arises for these "sides" looks like a failure, or at least a nuisance, from another side. To apply addiction definitions on people enforces involvements, and thus diagnoses achieve classifying "aways" as unwanted and inappropriate in the light of other expectations that are supported through these diagnoses. Psychiatry achieves such enforcement. Resistance against psychiatry, as has picked up again in the last decade, achieves a defense of these aways, of the people who are diagnosed with "diseases" and their involvements, opposing the official and powerful medical-legal coalitions against them. Suspending the belief in psychiatric diagnoses is a prerequisite for being able to offer a sensible sociological account of the interactional dynamics involved in the scenes in which psychiatry becomes active. 


\section{BIBLIOGRAPHY}

ADLER Patricia, Peter Adler \& Patrick O'Brien (2012). Drugs and the American Dream, An Anthology, New York, Wiley.

ALBAS Cheryl \& Daniel Albas (2003). "Motives”, in Reynolds Larry T. \& Herman-Kinney Nancy J. (eds), Handbook of Symbolic Interacionism, Walnut Creek, AltaMira, pp. 349-366.

AMERICAN PSYCHIATRIC ASSOCIATION (2000). Diagnostic and statistical manual of mental disorders (4th ed., text rev.), Washington DC, APA.

BECKER Howard (1963). Outsiders, New York, Free Press.

BERNE Eric (1964). Games People Play, New York, Grove Press.

BLUM Alan \& Peter McHugh (1971). "The Social Ascription of Motives", American Sociological Review 36, 98-109.

BLUMER Herbert (1998) [1969]. Symbolic Interactionism: Perspective and Method, Berkeley, University of California Press.

BOWERS Len (1998). The Social Nature of Mental Illness, London, Routledge.

BRENNER Viktor (1997). "Psychology of computer use: XLVII. Parameters of Internet use, abuse and addiction: The first 90 days of the Internet usage survey", Psychological Reports, 80, pp. 879-882.

CASTEL Robert (1983). Die psychiatrische Ordnung. Das goldene Zeitalter des Irrenwesens, Frankfurt, Suhrkamp.

CHOU Chien, Linda Condron \& John C. Belland (2005). "A Review of the Research on Internet Addiction”, Educational Psychology Review 17 (4), pp. 363-388.

CLARK Marilyn (2011). “Conceptualising Addiction: How Useful is the Construct?", International Journal of Humanities and Social Science 1 (13), pp. 55-64.

CONRAD Peter \& Joseph W. Schneider (1985). Deviance and Medicalization. From Badness to Sickness, Philadelphia, Temple University Press.

COOPER David (2001) [1967]. Psychiatry and Antipsychiatry, London, Routledge.

DELLWING Michael (2009). “The interactionist triangle”, http://www.uni-kassel.de/fb05/

fileadmin/datas/fb05/The_interactionist_triangle.pdf Originally published as: "Das

interaktionistische Dreieck." Monatsschrift für Kriminologie und Strafrechtsreform, 92, pp. 3-17.

DELLWING Michael (2010). “Wie wäre es, an psychische Krankheiten zu glauben ?”, Österreischische Zeitschrift für Soziologie, 35, pp. 40-58.

DELLWING Michael (2011a). “Truth in Labeling: Are Descriptions All We Have?” Deviant Behavior 32 (7), pp. 653-675.

DELLWING Michael (2011b). “Langeweile mit der Eindeutigkeit”, in Peters Helge and Dellwing Michael, Langweiliges Verbrechen, Wiesbaden, Springer VS, pp. 197-212.

DELLWING Michael (2013). Resisting Alignment, Under review.

EHRENREICH Barbara \& D. English (1973). Complaints and Disorders. The Sexual Politics of Sickness.,New York, Feminist Press. 
FINE Gary A. (2010). “The Sociology of the Local”, Sociological Theory 28 (4), pp. 355-376.

FISH Stanley (1989). Doing What Comes Naturally, Durham, Duke.

GOFFMAN Erving (1961). Asylums: Essays on the Social Situation of Mental Patients and Other Inmates, New York, Doubleday Anchor.

GOFFMAN Erving (1963). Behavior in Public Places: Notes on the Social Organization of Gatherings, Glencoe, The Free Press.

GOFFMAN Erving (1971). Relations in Public, New York, Basic Books.

GUSFIELD Joseph R (1986). Symbolic Crusade: Status Politics and the American Temperance Movement, Chicago, University of Illinois Press.

HEWITT John P. \& Peter M. Hall (1973). “Social Problems, Problematic Situations, and Quasi-

Theories", American Sociological Review, 38, pp. 367-374.

KIRK Stuart A. \& Herb Kutchins (1992). The Selling of DSM, New York, Free Press.

KIRK Stuart A. \& Herb Kutchins (1997). Making Us Crazy, New York, Free Press.

KIRSCH Irving (2009). The Emperor's New Drugs. Exploding the Antidepressant Myth, London, The Bodley Head.

LAING Ronald D. (1978). Sanity, Madness and the Family, London, Penguin Books.

LYMAN Stanford M. \& Marvin B. Scott (1989). A Sociology of the Absurd, Dix Hills, New York, General Hall.

MILLS C. Wright (1940). "Situated Action and Vocabularies of Motive", American Sociological Review, 5, pp. 904-913.

MONCRIEFF Joanna (2009). The Myth of the Chemical Cure, Hampshire, Palgrave Macmillan.

MURALI Vijaya \& Sanju George (2007). "An overview of internet addiction", Advances in Psychiatric Treatment, 13, pp. 24-30.

PRUS Robert (1996). Symbolic Interaction and Ethnographic Research: Intersubjectivity and the Study of Human Lived Experience, Albany, New York, State University of New York Press.

PRUS Robert (1997). Subcultural Mosaics and Intersubjective Realities: An Ethnographic Research Agenda for Pragmatizing the Social Sciences, Albany, New York, State University of New York Press.

RORTY Richard (1982). Consequences of Pragmatism, Minneapolis, Minnesota University Press.

RORTY Richard (1989). Contingency, Irony, and Solidarity, New York, Cambridge University Press.

RORTY Richard (1999). Philosophy and Social Hope, London, Penguin.

SCHEFF Thomas (1984). Being Mentally Ill. A Sociological Theory, Hawthorne.

SCHEPER-HUGHES Nancy \& Anne M. Lovell (1987). Psychiatry Inside Out. The Selected Writings of Franco Basaglia, New York, Columbia University Press.

SCHETSCHE Michael (2007). "Sucht in wissenssoziologischer Perspektive”, in Dollinger Bernd \& Schmidt-Semisch Henning, Sozialwissenschaftliche Suchtforschung, Wiesbaden, VS Verlag für Sozialwissenschaften, pp. 113-130.

SCHMIDT-SEMISCH Henning (2010). “Doing Addiction. Überlegungen zu Risiken und Nebenwirkungen des Suchtdiskurses”, in Paul Bettina, Schmidt-Semisch Hennig (eds), Risiko 
Gesundheit. Zu Risiken und Nebenwirkungen der Gesundheitsgesellschaft, VS-Verlag, Wiesbaden, pp. 143-162.

SHALIN Dmitri (1986). "Pragmatism and Social Interactionism", American Sociological Review, 51, pp. 9-29.

SHALIN Dmitri (1992). “Critical Theory and the Marxist Challenge”, American Journal of Sociology, 98, pp. 237-279.

SHAPIRA Nathan A., GOLDSMITH Toby D., KECK Paul E., KHOSLA Uday M. \& MCELROY Susan L. (2000).

"Psychiatric features of individuals with problematic Internet use", Journal of Affective Disorders, 57, pp. 267-272.

SHOWALTER Elaine (1987). The Female Malady, London, Virago.

SHOWALTER Elaine (1990). “Double Flowers: Hysteria, Feminism and Gender”, Paper presented at the Wellcome Symposium on the History of Medicine, London.

STOKES Randall \& John P. Hewitt (1976). “Aligning Actions”, American Sociological Review, 41, pp. 838-849.

STRAUSS Anselm (1993). Continual Permutations of Action, New York, De Gruyter.

SULLIVAN Harry Stack (1964). The Fusion of Psychiatry and Social Science, New York, Norton.

SZASZ Thomas (1974). The Myth of Mental Illness. Foundations of a Theory of Personal Conduct, New York, Harper \& Row.

THORENS Gabriel, KHAZAAL Yasser, BILLIEUX Joël, VAN DER LINDEN Martial \& ZULLINO Daniele (2009). “Swiss Psychiatrists' Beliefs and Attitudes About Internet Addiction”, Psychiatric Quarterly, 80 (2), pp. 117-123.

USSHER Jane (1992). Women's Madness, Amherst, University of Massachusetts Press.

USSHER Jane (1997). Body Talk, London, Routledge.

WALTER Susanne \& Michael Schetsche (2003). "Internetsucht - eine konstruktionistische

Fallstudie“, Soziale Probleme, 14 (1), pp. 5-40.

WHITAKER Robert (2010). Mad in America: Bad Science, Bad Medicine, and the Enduring Mistreatment of the Mentally Ill, New York, Basic Books.

WHITAKER Robert (2011). Anatomy of an Epidemic: Magic Bullets, Psychiatric Drugs, and the Astonishing Rise of Mental Illness in America, New York, Random House.

YOUNG Kimberly S. (1998). "Internet Addiction: The Emergence of a New Clinical Disorder", CyberPsychology \& Behavior, 1 (3), pp. 237-244.

\section{NOTES}

1. While this is not the place to discuss this, it is notable that the psychiatric vocabulary in the DSM has retained the word "disorder" while placing an absolute emphasis, in DSM-III and beyond, on the medical model and its conjoined "illness" narrative, the word is the only nod to psychoanalysis left after the approach was de facto exorcised from the DSM in the 1980s and remains at odds with its medicalized content and, especially, treatment.

2. This paper was written shortly before the newest version, DSM-V, was issued in May 2013.

3. Emphasis by the author. 
4. This does not mean that they have to take whatever role offered, just that they have to show that their role negotiation stays in reciprocal interaction with, and ritual deference to, the other participants of the interaction.

\section{ABSTRACTS}

There is a long, though now dormant, dispute between sociology and psychiatry. The most famous antagonism came with the antipsychiatry movement, which sought to disqualify mental illness explanations as "false," as naïve and simplistic objectifications of complex interactional processes. Effectful as this antagonism was, it effectively pulled up walls between psychiatry and sociology that remain visible today.

A contemporary sociological appraisal can transcend this conflict by resuscitating old insights generated by Erving Goffman, who famously stated that did psychiatry not exist, we would have to invent it (1971). To Goffman, as to pragmatists at-large, meanings are social products. That not only applies to the biomedical vocabulary, but also to any vocabulary critics wish to put in its stead, making the constructionist argument toothless for critical purposes (cf. Fish 1989). Rather than debate their truth or falsehood, pragmatists focus on the social contexts and situations in which they arise and on what is achieved by them in these concrete situations.

Psychiatric categorizations of people can then be reframed as a tool to mend broken situations where sociation was in severe disarray in ways that protect valuable social realities: placing the causal source of the disarray in people's bodies provides a clear pinpoint for influence work. It is often a last effort to affect actors whose justifications have retreated into "internalisms" such as "feelings" that became unreachable for other social negotiations of meaning or those who have changed behavior in ways that make them unpredictable or predictable in unwelcome ways. This is not an abstract unpredictability or unwelcome predictability, but one only to those who expect different roles from them.

This dynamic is well visible in the case of what the biomedical model now calls "Internet addiction." The paper will apply Goffman's work on mental illness as a disturbance of the order of "place" to this contemporary expansion of the diagnostic canon. Place is here negotiated via time: "Internet addiction" is ascribed to those whose priorities concerning their time management worry, sadden and anger others. These others define their relationship and other activities functional to that relationship (i.e. concern with professional and social duties) as "high priority" and seek to enforce this priority over other uses of time that they mark as "useless," as "a misdistribution of time." The illness vocabulary is thus a practical tool to socially control and enforce "correct" time-management when other tools fail.

Il existe une longue histoire de conflits, bien qu'aujourd'hui moins ouverts, entre la sociologie et la psychiatrie. L'antagonisme le plus connu est venu du mouvement antipsychiatrique, qui a essayé de disqualifier les conceptions psychiatriques de la maladie mentale en tant qu'objectifications naïves et simplistes de processus interactionnels en réalité complexes. Quels que soient les effets de cet antagonisme, celui-ci a effectivement érigé des cloisons entre sociologie et psychiatrie qui demeurent visibles aujourd'hui. Ce conflit peut être dépassé en recourant à d'anciennes perspectives, comme celles d'Erving Goffman qui avait notoirement dit que si la psychiatrie n'existait pas, il faudrait l'inventer (1971). Pour Goffman, ainsi que pour les pragmatistes en général, le sens est un produit social. Ceci ne s'applique pas seulement au 
vocabulaire biomédical, mais aussi à tout vocabulaire que ses détracteurs souhaitent lui opposer, ce qui diminue la portée critique de l'argument constructiviste (cf. Fish 1989). Plutôt que de débattre de leur véracité, les pragmatistes se concentrent sur les contextes et situations sociales dans lesquels les mots émergent, et sur ce que ces derniers produisent concrètement. Ainsi, les catégorisations psychiatriques peuvent être repensées comme des outils servant à corriger des situations de rupture de sociabilité en situant la cause du bouleversement dans le corps des individus de manière à préserver des réalités sociales valorisées. C'est une manière d'atteindre des acteurs qui, retranchés derrière des justifications d'ordre interne comme les "émotions ", évitent d'autres négociations du sens, ou qui ont changé leurs comportements socialement indésirables ou imprévisibles. Cette dynamique est bien visible dans le cas de ce que la perspective biomédicale nomme «l'addiction à Internet». Cet article puise dans le travail de Goffman sur la maladie mentale en tant que perturbation de l'ordre «dans la place» pour l'appliquer à cette extension contemporaine du canon diagnostique. L'espace est ici négocié via le temps : "l'addiction à Internet » est attribuée à ceux dont les priorités de gestion du temps inquiètent, attristent ou fâchent autrui. Ces autruis accordent à leur relation et aux activités qui leur sont complémentaires (par exemple des responsabilités professionnelles et sociales) une haute priorité et cherchent à imposer cette priorité au détriment d'autres usages du temps considérés comme inutiles ou mal agencés. Le vocabulaire pathologique constitue ainsi un outil pratique pour le contrôle social et l'imposition d'une gestion « correcte » du temps là où d'autres outils ont échoué.

\section{INDEX}

Mots-clés: addiction, addiction à Internet, pragmatisme, Goffman, diagnostic

Keywords: addiction, Internet addiction, pragmatism, Goffman, diagnosis

\section{AUTHOR}

\section{MICHAEL DELLWING}

University of Kassel, Department of Sociology 